\title{
Faisal international prizes in search of winners
}

\section{Riyadh}

THE short and somewhat shaky history of the King Faisal International Prizes was continued this week with the 1987 award ceremony in the Saudi-Arabian capital. Of the five annual prizes of $£ 60,000$ each, two of the three in Islamic/Arabic studies were not awarded for lack of nominations of sufficient quality. But there is no disputing the credentials of this year's winners of the medicine and science prizes, New Zealander Professor Barrie Jones of the International Centre for Eye Health at Moorfields Hospital in London and Sir Michael Atiyah, who is British and is professor of geometry at Oxford University. This year's only prize for Islamic/Arabic studies went to Sheikh Abubakar Mahmud Gumi, Grand Mufti of Nigeria for translating the Koran into Hausa.

Atiyah's prize, given for his work in the area between geometry and theoretical physics, is the first to be awarded for mathematics, one of the four subject areas for which the science prize is given in rotation. Chemistry was the area last year, and Dr Michael Berridge the winner. And in 1984 for physics, the prize was shared by Drs Gerd Binnig and Heinrich Roher,

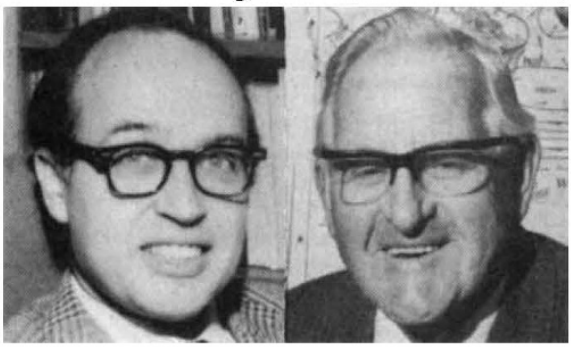

Saudi winners: Sir Michael Atiyah (left) and Dr Barrie Russell Jones.

who won Nobel prizes last year. But in 1983 , its first year, and in 1985 , the science prize was not awarded, again "because nobody good enough was nominated", says Prince Khaled al Faisal, director general of the King Faisal Foundation which created the prize.

The medicine prize, now in its sixth year, has always found a winner. It is awarded each year in a different area of medicine chosen to be of particular relevance to developing countries. Malaria, diarrhoeal disease and viral hepatitis have been among past topics. This year's subject, chosen by last year's jurors, was prevention of blindness. Jones is cited for his contributions to the prevention and treatment of trachoma and onchocerciasis.

In particular, his work established that chlamydial infections are responsible for trachoma. More recently, he has been pressing for the provision of simple programmes of teaching personal hygiene and health to rural communities in de- veloping countries. That, he says, is a far more effective way to tackle blindness, 80 per cent of which could be simply prevented, than first to build a swanky specialist eye hospital, like the King Kalid Eye Hospital in Riyadh.

The annual process of finding prizewinners bears some resemblance to the Nobel process. With few exceptions, candidates have to be nominated by institutions: the Royal Society of London and the World Health Organization were among the nominees of this year's prizes. Relevant nominations are then refereed by anonymous experts in the subject area. The experts' reviews and the primary and other material are then sent to the relevant jury of "leading international scholars".

Foundation officials deny that sex, religion or race are factors in picking the winners, and jurors see no evidence of it either. On the other hand, of 14 science or medicine prize-winners so far, none has been female or Jewish. A sample of comparable size from other major prizes might also contain no women but would be unlikely not to include a Jew. Peter Newmark

\section{Argentina to be sole user of nuclear dump London $\neq 18$}

Argentina's proposed nuclear waste dump in the Sierra del Media area will not be 'internationalized', at least until the end of the century, according to Cesar Arias, a spokesman for the radiological and security protection office of the National Atomic Energy Agency (CNEA). Speaking on radio last month, he said that the decision whether or not to allow other countries to use the site is not due to be taken until the year 2000 , and will then depend not on the CNEA but on the government of the day. Commenting on protests against the dump (to be sited $60 \mathrm{~km}$ from Gastre, in Chubut province), Arias said that the granite of the region made it one of the safest places possible. He dismissed the opposition as "normal", as, he said, nuclear energy had created among the general public "an aura of mystery, passion and even sex (sic)".

Hints that the dump would be made available to imported waste have been rife in Argentine political circles. One likely applicant to use the dump (if and when it becomes available) would be Brazil, where no less than 17 dumping sites (including some ocean sites) have been proposed and have been met with widespread opposition. Vera Rich
Space museum exhibit 'escapes'

\section{Washington}

THE Smithsonian Institution's Air and Space Museum, one of the most visited of Washington's public museums, has come to the rescue of Magellan, the Venus radar mapping mission scheduled for launch in 1989. Magellan was to have been launched by the shuttle carrying a Centaur upper stage. But last June, NASA (the National Aeronautics and Space Administration) cancelled the shuttle/Centaur Program, forcing Magellan's managers to switch to IUS, the Inertial Upper Stage.

Because IUS is less powerful than the Centaur, weight had to be trimmed. A lighter upper-stage adapter was built, saving $127 \mathrm{~kg}$, but this meant carrying out new structural load analyses. Typically, that would have been done with the prototype satellite, but that was already being used in the satellite construction. With no way to perform the tests, the launch date was in jeopardy:

Enter the museum's Voyager spacecraft exhibit. The bus on the satellite on display

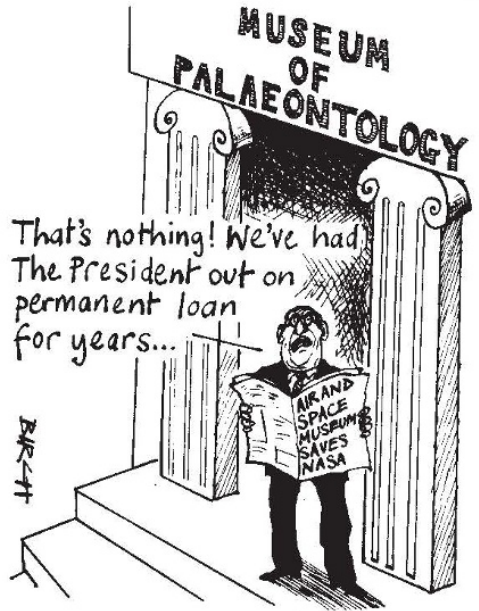

was close enough to the Magellan bus to be used in the tests. So, in January, workers removed the bus from the exhibit, sending it by truck to Martin Marietta's Denver plant where it will be modified to fit Magellan specifications.

By using the Voyager bus from the museum, NASA saved approximately $\$ 1$ million. But Magellan science manager Neil Nickle says that if the museum had not cooperated, no amount of money would have made it possible to construct another bus and still complete all tests by the scheduled April 1989 launch date.

Exhibits rescued from the Air and Space Museum have been useful for a real space mission before. Last November, the Air Force launched the Polar Beacon Experiment and Auroral Research satellite with parts from a Transit 5A satellite that had been hanging in the museum (see Nature 322, 297; 1986).

Joseph Palca 